\title{
ARSITEKTUR CONTAINER DOCKER PADA APLIKASI EXPERT ASSIST DENGAN TEKNOLOGI NODE.JS, EXPRESS FRAMEWORK \& CLOUD DATABASE NoSQL MONGODB ATLAS
}

\author{
Sutanto $^{1}$, Waliadi Gunawan ${ }^{2}$, aeshal $^{3}$ \\ Program Studi Teknik Informatika Universitas Banten Jaya \\ Email: sutanto@unbaja.ac.id ${ }^{1}$, waliadigunawan@unbaja.ac.id ${ }^{2}$, \\ Faeshal111@gmail.com ${ }^{3}$
}

\begin{abstract}
In the world of software development, the crusial thing we must do is design the architecture. We can said the system is good if it has a good architecture too, because the system architecture will affect the performance of applications itself, from the architecture we can also read what technology is used until security aspect. The main problems that $i$ want to solve are two things, first the problem in the process of software development which will be solve by implementing Docker container architecture \& Node.JS and second problems is in society that will be solve by the Expert Assist application. In the case of software development the problems is often when developing applications the architecture is not scalable, conflicts between applications in the system, services that are still centralized, application portability issues, security optimization problems and different environments between the development and production server that will affect developer productivity, problems about not independent and robustless app, resource efficiency and the problem with blocking code that appear in server side conventional programming languages. The problem in society is the difficulty to finding a mentor who can help us to solve the problems we have, that is why Expert Assist application was made. Expert Assist is a web based online platform that will help all people in various fields to finding a mentor who is an expert in his field because not all problems can be solved by independent research or self-taught, if the problem is very complex we need someone who can help us to provide advice in order to solve our problem.
\end{abstract}

Keyword : Architecture, Docker, Express, MongoDB, Node.JS

\section{PENDAHULUAN}

Arsitektur perangkat lunak adalah sebuah proses untuk mendefinisikan struktur dari suatu aplikasi yang dapat memenuhi seluruh kriteria dari sisi teknis dan juga operasional, dengan pertimbangan kualitas seperti performance, security dan Maintainability. Seiring perkembangan zaman teknologi baru terus bermunculan, hal ini disebabkan karena teknologi lama sudah kurang relevan untuk menangani kebutuhan pengguna yang semakin banyak juga tentu menginginkan respon yang semakin cepat dari sistem. Arsitektur sangat penting 
disini, karena kita tidak mungkin membuat sistem yang punya performa bagus bila arsitektur yang dibuat masih kurang baik.

Penelitian ini difokuskan pada dua permasalahan utama yang sering dialami, pertama permasalahan pada masyarakat umum dan kedua permasahan dalam pengembangan perangkat lunak (software development). Permasalahan pada masyarakat yang sering dialami adalah sulitnya mencari mentor yang ahli dibidangnya yang bisa membantu kita memecahkan masalah yang kita hadapi. Karena pasti dalam hidup akan mendapati masalah yang kompleks dan kita tidak bisa mengandalkan riset mandiri atau autodidak terus menerus. Karena itu kita perlu mentor yang bisa memberikan arahan untuk permasalahan yang kita hadapi. Urgensi dari pembuatan aplikasi Expert Assist adalah saat ini di Indonesia belum ada platform yang menghubungkan antara expert dan user, untuk itulah dirasa perlu dibuat platform untuk menghubungkan mereka. Expert Assist pada dasarnya adalah platform berbasis web yang akan mempertemukan mentor atau expert untuk menyelesaikan masalah user tanpa harus bertemu secara langung karena dapat langsung berinteraksi lewat platform Expert Assist sehingga masyarakat tidak perlu bingung lagi kalau ada masalah yang kompleks ingin bertanya kepada siapa, cukup lewat aplikasi Expert Assist lalu pilih mentor yang sesuai dengan masalah yang dihadapi dan lakukan pembayaran. Hal ini juga akan membuka peluang penghasilan tambahan untuk para expert disemua bidang bukan hanya IT yang bisa bergabung bersama sehingga saling menguntungkan bukan hanya bagi user dan mentor tetapi kita sebagai pengembang aplikasi mendapat keuntungan dari sistem bagi hasil 95\% untuk mentor dan 5\% untuk pengelola. Expert Assist akan memastikan mentor yang ada sangat kompeten dengan serangkaian tes yang akan dilewati pada saat proses pendaftaran mentor. Sehingga kualitas mentor akan berbanding lurus dengan kepuasan user. Sedangkan permasalahan pada pengembangan perangkat lunak khususnya pada pembuatan arsitektur aplikasiyaitu aplikasi yang dibangun riskan mengalami konflik dengan aplikasi lain, karena berjalan disatu mesin yang sama dan hal ini bisa jadi masalah besar yang akan menyebabkan sistem lumpuh, masalah kedua muncul saat proses development khusunya dalam tim aplikasi yang dikembangkan tidak portable, masing masing developer harus menginstall environment yang dibutuhkan aplikasi untuk bisa berjalan. Masalah muncul bila aplikasi yang dikembangkan 
bukan hanya satu, sangat merepotkan dan kurang efisien bila kita mengintall semua tools dan platform yang dibutuhkan semua aplikasi yang berjalan pada komputer developer. Masalah ketiga adalah permasalahan keamanan, tentu aplikasi yang kita kembangkan butuh optimasi kemanan yang extra oleh karena itu kita tidak bisa mengandalkan konfigurasi keamanan yang kita buat sendiri, harus ada perlindungan extra untuk melindungi aplikasi kita bila sewaktu waktu ada serangan masuk. Masalah lain adalah aplikasi sulit diperbesar dan diperkecil sesuai kebutuhan pengguna, tidak mungkin kita terus menereus melakukan upgrade hardware dari server karena pasti biaya yang ditimbulkan akan sangat besar, oleh karena itu kita butuh Docker yang akan membantu saat proses horizontal scaling. Docker juga akan mereplikasi aplikasi sesuai dengan kebutuhan pengguna, bilamana pengguna yang mengakses aplikasi sudah berkurang maka Docker akan mematikan Container untuk menghemat sumber daya tapi apabila pengguna yang mengakses aplikasi sangat banyak maka Docker secara otomatis akan mereplikasi Container sehingga kebutuhan pengguna akan terpenuhi yang kembali lagi akan berdampak pada performa sistem. Masalah terakhir pada segi arsitetktur adalah ketergantungan antara yang aplikasi satu dengan aplikasi yang lainnya, akan jadi masalah dimana apabila satu aplikasi mengalamai kendala maka akan mempengaruhi aplikasi lain yang berjalan disistem yang sama. Semua masalah tadi dapat diatasi dengan implementasi teknologi Container Docker. Docker merupakan teknologi Container yang menyediakan platform terbuka untuk developer maupun sysadmin untuk dapat membangun, mengemas dan menjalankan aplikasi dimanapun sebagai sebuah wadah ringan yang disebut dengan Container. Berbeda dengan virtualisasi yang mana aplikasi berjalan diatas hypervisor dan guest OS. Docker dapat menjalankan aplikasi langsung tanpa kedua hal tadi. Hal inilah yang membuat Docker lebih hemat sumber daya server.

Masalah lain dari segi teknologi bahasa pemrograman yang menganut blocking code seperti PHP, Pearl dan lainnya adalah request yang masuk akan menunggu sampai selesai sebelum menjalankan request berikutnya. Ini membuat kerja aplikasi melambat dan juga paradigma jika kita mengembangkan aplikasi web kita menggunakan bahasa yang berbeda antara frontend dan backend, ini sedikit merepotkan karena environment antara client side dan server side berbeda. 
Maka disinilah Node.JS hadir dengan konsep "satu bahasa untuk mengatur semuanya". Bila selama ini kita mengenal JavaScript sebagai bahasa pemrograman yang berjalan disisi client saja, maka Node.JS ada untuk melengkapi peran JavaScript sehingga bisa juga berlaku sebagai bahasa pemrograman yang berjalan disisi server, seperti halnya PHP, Ruby, Perl dan sebagainya. Node.JS memiliki pustaka server HTTP sendiri sehingga memungkinkan untuk menjalankan web server tanpa menggunakan program web server seperti Apache atau Nginx. Untuk itu dengan adanya aplikasi Expert Assist yang menggunakan arsitektur Container Docker ini diharapkan dapat memecahkan dua masalah sekaligus yaitu masalah di masyarakat dan masalah dalam pengembangan perangkat lunak.

Pada penelitian ini akan dibahas aplikasi expert assist yang bisa digunakan user dengan telah memenuhi persyaratan tertentu yang secara umum terdiri beberapa modul sebagai berikut: register, login, test mentor, manajemen profile, mencari dan memilih mentor, proses pembayaran, Chatting, atur jadwal dann konfirmasi, proses mentoring, mentor review, permintaan Tarik dana dan konfirmasi dan proses pencairan dana dengan bebagai sub aktivitas atau sub modul didalam tiap tiap modul. Secara arsitektur aplikasi ini menggunakan arsitektur Container Docker, dan dijalankan pada ekosistem localhost, dan versi docker yang digunakan adalah 19.03.5. sedangkan databse yang digunakan adalah mongoDB versi 4.2.0 dengan menggunakan layanan cloud database Atlas. Payment Gateway yang digunakan yaitu Stripe dengan integrasi kartu kredit Visa, Master Card, American Express, Discover, Dinner Club dan JCB. Tidak menggunakan payment gateway bank local. 5.Teknologi Backend yang digunakan adalah Node.JS versi 12.16 dan untuk Framework yaitu Express versi 4.17.1 dan untuk teknologi Frontend yang digunakan adalah Bootstrap versi 4.4.4 dan EJS versi 3.0.1.

Tujuan dari penelitian ini adalah: membangun arsitektur sistem yang berjalan diatas Container sehingga konflik antar aplikasi bisa diatasi walaupun berjalan disatu mesin yang sama (independent), bisa diperbesar dan diperkecil dengan mudah sesuai kebutuhan (scalable), memiliki tingkat keamanan tinggi (secure) dan portable yang akan mendorong produktivitas developer serta aplikasi dapat berdiri sendiri sehingga apabila salah satu aplikasi bermasalah tidak akan 
mempengaruhi aplikasi lain (robust) dan sistem tetap berjalan normal dengan tetap menghemat sumber daya, mampu mengimplementasikan bahasa pemrograman JavaScript yang berjalan tidak hanya disisi frontend (client side) tapi juga berjalan disisi backend (server side) dan dapat membuat aplikasi yang dapat memecahkan masalah di masyarakat yaitu sulitnya mencari mentor yang ahli dibidangnya untuk membantu menyelesaiakan masalah yang dihadapi.

Landasan Teori

\section{METODE PENELITIAN}

Yang menjadi objek penelitian pada penelitian ini adalah adanya aktivitas para user dalam interaksinya dengan expert di dunia maya yang belum terwadahi secara khusus terkait dalam penggunaan Docker Hosting / VPS dan Cloud Database Hosting. Selanjutnya adalah penjelasan metodologi penelitian yang diterapkan pada penelitian ini:

a. Metode penelitian adalah serangkaian tata cara atau langkah yang sistematis atau terstruktur dan dilakukan oleh seorang peneliti dengan tujuan menjawab pertanyaan dari rumusan masalah yang ada.

b. Desain penelitian: desain penelitian yang digunakan dalam penelitian ini bersifat deskriptif. Penelitian deskriptif adalah penelitian yang diarahkan untuk memberikan gejala- gejala, fakta-fakta, atau kejadian kejadian secara sistematis dan akurat mengenai sifat-sifat populasi atau daerah tertentu. Dalam hal ini berupa sistem informasi yang sedang berjalan serta entitasentitas yang terkait dalam perusahaan atau instansi yang menjadi objek penelitian. Metode deskriptif dilakukan dengan cara mengumpulkan informasi aktual secara rinci mengenai masalah yang akan diteliti.

c. Jenis dan metode penelitian: sumber data dan informasi penelitian ini diperoleh dengan menggunakan metode tertentu dan dipilah berdasarkan jenis data yang diperlukan. Sumber data primer berasal dari wawancara an observasi sedangkan Sumber data sekunder: data yang diambil dari suatu sumber dan biasanya data tersebut sudah dikompilasi lebih dahulu dari berbagai sumber pustaka termasuk internet.

d. Metode Pendekatan dan pengembangan Sistem Infromasi, metode yang digunakan adalah SDLC (Software Development Life Cycle) dengan 
pendekatan metode waterfall. Model ini mengusulkan sebuah pendekatan perkembangan perangkat lunak yang sistematik dan sekuensial yang dimulai pada tingkat dan kemajuan sistem pada seluruh analisis, desain, kode, pengujian dan pemeliharaan. Menurut Roger S. Pressman (2019) Waterfall adalah model klasik yang bersifat sistematis, berurutan dalam membangun software. Nama model ini sebenarnya adalah Linear Sequential Model. Model ini sering disebut juga dengan classic life cycle. Model ini melakukan pendekatan secara sistematis dan berurutan. Disebut dengan waterfall karena tahap demi tahap yang dilalui harus menunggu selesainya tahap sebelumnya dan berjalan berurutan. Adapun tahap dalam metode waterfall adalah sebagai berikut :

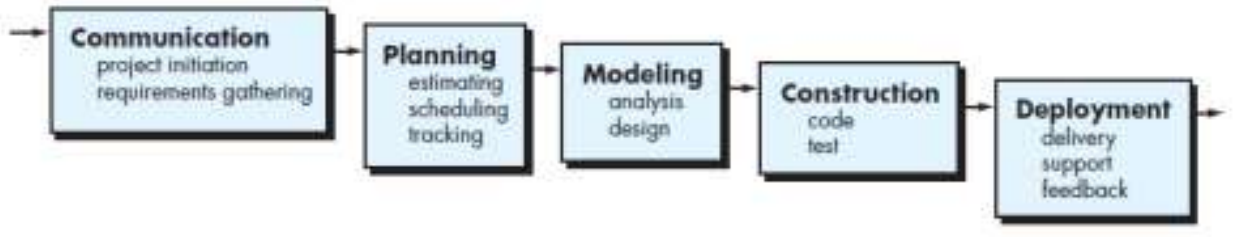

Gambar 1. Tahapan Metode Waterfall

e. Pengujian Software

Pengujian software adalah cara atau teknik untuk menguji perangkat lunak, mempunyai mekanisme untuk menentukan data uji yang dapat menguji perangkat lunak secara lengkap dan mempunyai kemungkinan tinggi untuk menemukan kesalahan. Metode/teknik pengujian software yang digunakan pada penelitian ini adalah metode black box. black box berusaha menemukan kesalahan dalam kategori:

- Fungsi-fungsi yang tidak benar atau hilang,

- Kesalahan interface,

- Kesalahan dalam struktur data atau akses basisdata eksternal,

- Validitasi fungsional,

- Inisialisasi dan kesalahan terminasi.

- Batasan dari suatu data 


\section{PEMBAHASAN}

1. Analisa Prosedur yang berjalan

Belum adanya platform yang memfasilitasi/menghubungkan user dengan expert/mentor untuk saling bertukar pikiran menyelesaikan masalah yang sedang dihadapi. Maka dari itu dibuatnya sistem ini karena berdasarkan pengalaman sulit sekali memecahkan masalah yang kompleks khususnya dalam sisi technical secara otodidak, tentu kita memerlukan seseorang yang sudah kompeten dibidangnya untuk memberikan masukan dan arahan guna memecahkan masalah yang dihadapi.

2. Evaluasi Sistem yang berjalan

Setelah dilakukan penelitian dengan melakukan analisa terhadap sistem yang berjalan baik secara dokumen maupun Prosedur maka berikut adalah evaluasi terhadap permasalahan sistem yang ada:

Tabel .1 Pemetaan Masalah dan Solusi

\begin{tabular}{|c|c|c|}
\hline No & Masalah & Solusi \\
\hline 1 & $\begin{array}{l}\text { Masalah dalam pengembangan } \\
\text { perangkat lunak khususnya dalam } \\
\text { pembangunan arsitektur sistem, } \\
\text { yaitu masalah konflik aplikasi bila } \\
\text { berjalan di satu mesin yang sama, } \\
\text { sulitnya aplikasi diperbesar dan } \\
\text { diperkecil sesuai kebutuhan, } \\
\text { masalah aplikasi yang tidak } \\
\text { portable, environment yang } \\
\text { berbeda antara development dan } \\
\text { production server yang akan } \\
\text { mempengaruhi produktivas } \\
\text { developer, aplikasi yang tidak } \\
\text { independent \& kurang robust, } \\
\text { masalah optimasi keamanan serta } \\
\text { efisiensi sumber daya server. }\end{array}$ & $\begin{array}{l}\text { Node.JS hadir dengan konsep "satu } \\
\text { bahasa untuk mengatur semuanya". } \\
\text { Bila selama ini kita mengenal } \\
\text { JavaScript sebagai bahasa } \\
\text { pemrograman yang berjalan disisi } \\
\text { client saja, maka Node.JS ada untuk } \\
\text { melengkapi peran JavaScript sehingga } \\
\text { bisa juga berlaku sebagai bahasa } \\
\text { pemrograman yang berjalan disisi } \\
\text { server, seperti halnya PHP, Ruby, Perl } \\
\text { dan sebagainya. Node.JS memiliki } \\
\text { pustaka server HTTP sendiri sehingga } \\
\text { memungkinkan untuk menjalankan } \\
\text { web server tanpa menggunakan } \\
\text { program web } \\
\text { seperti Apache atau Nginx. Untuk itu } \\
\text { dengan adanya aplikasi Expert Assist }\end{array}$ \\
\hline
\end{tabular}




\begin{tabular}{|c|c|c|}
\hline 2 & $\begin{array}{l}\text { Masalah dalam masyarakat, yaitu } \\
\text { sulitnya menemukan mentor yang } \\
\text { bisa mengarahkan dan membantu } \\
\text { memecahkan masalah yang } \\
\text { kompleks, karena tidak selalu } \\
\text { masalah itu bisa diselesaikan } \\
\text { secara autodidak, kita butuh } \\
\text { mentor yang ahli dibidangnya } \\
\text { untuk membimbing kita untuk } \\
\text { membantu memecahkan masalah } \\
\text { yang kita hadapi }\end{array}$ & $\begin{array}{l}\text { yang menggunakan arsitektur } \\
\text { Container Docker ini diharapkan } \\
\text { dapat memecahkan dua masalah } \\
\text { sekaligus yaitu masalah di masyarakat } \\
\text { dan masalah dalam pengembangan } \\
\text { perangkat lunak. }\end{array}$ \\
\hline
\end{tabular}

3. Perancangan Sistem

Sebelum pembuatan aplikasi, maka perlu dimodelkan terlebih alur dari Bisnis Proses yang terjadi pada Bagian Survei. Mengingat rancangan proses yang akan dilakukan adalah secara Online, maka pemodelan yang dilakukan adalah menggunakan Unified Modelling Language (UML). Dengan bentuk usecase diagram sebagai berikut:

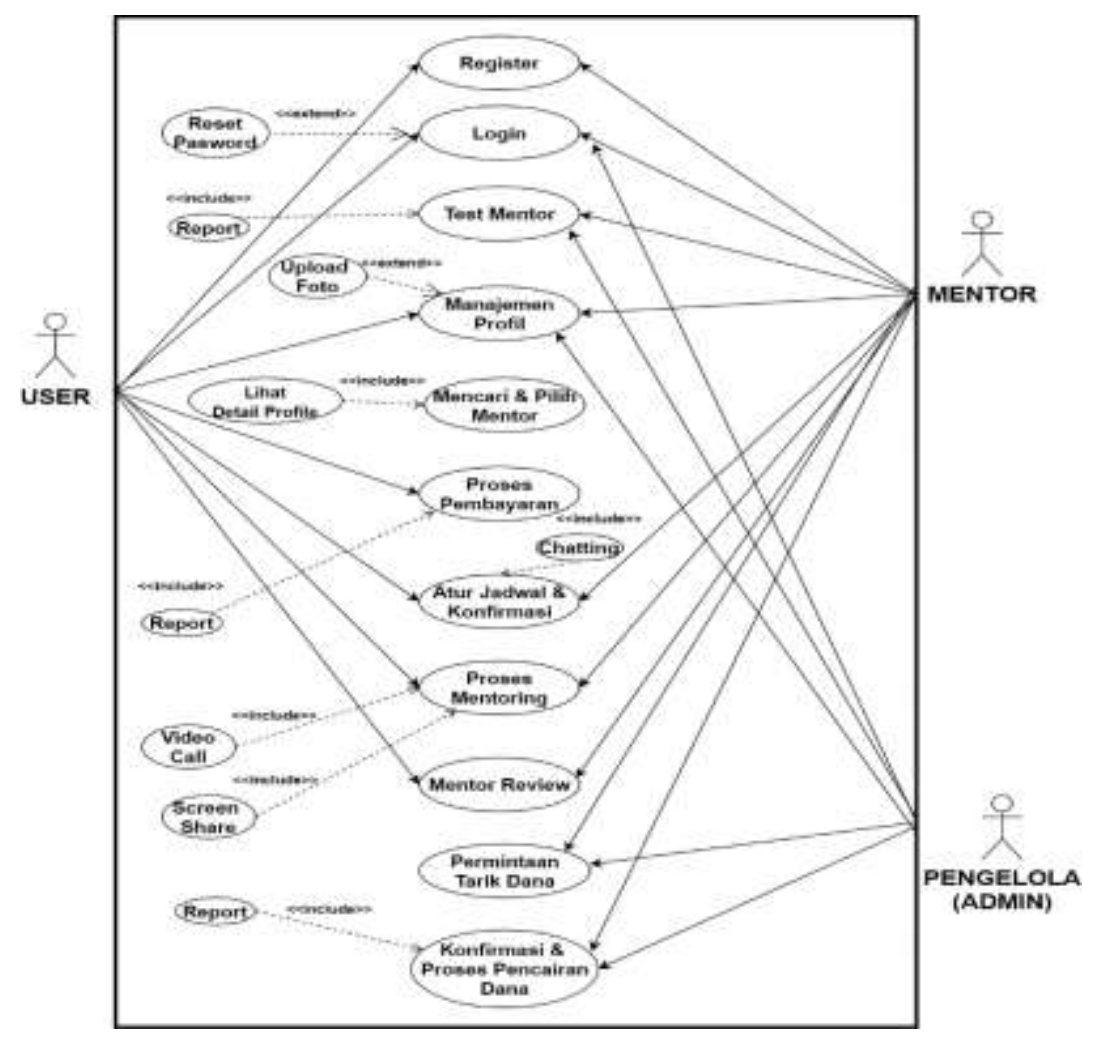

Gambar 2. Usecase Diagram 
Untuk menggambarkan kelas-kelas dalam sebuah sistem dan hubungannya antara satu dengan yang lain serta dimasukkan pula atribut dan operasi maka dibuatlah class diagram. Berikut adalah gambar class diagram sistem yang dirancang pada penelitian ini:

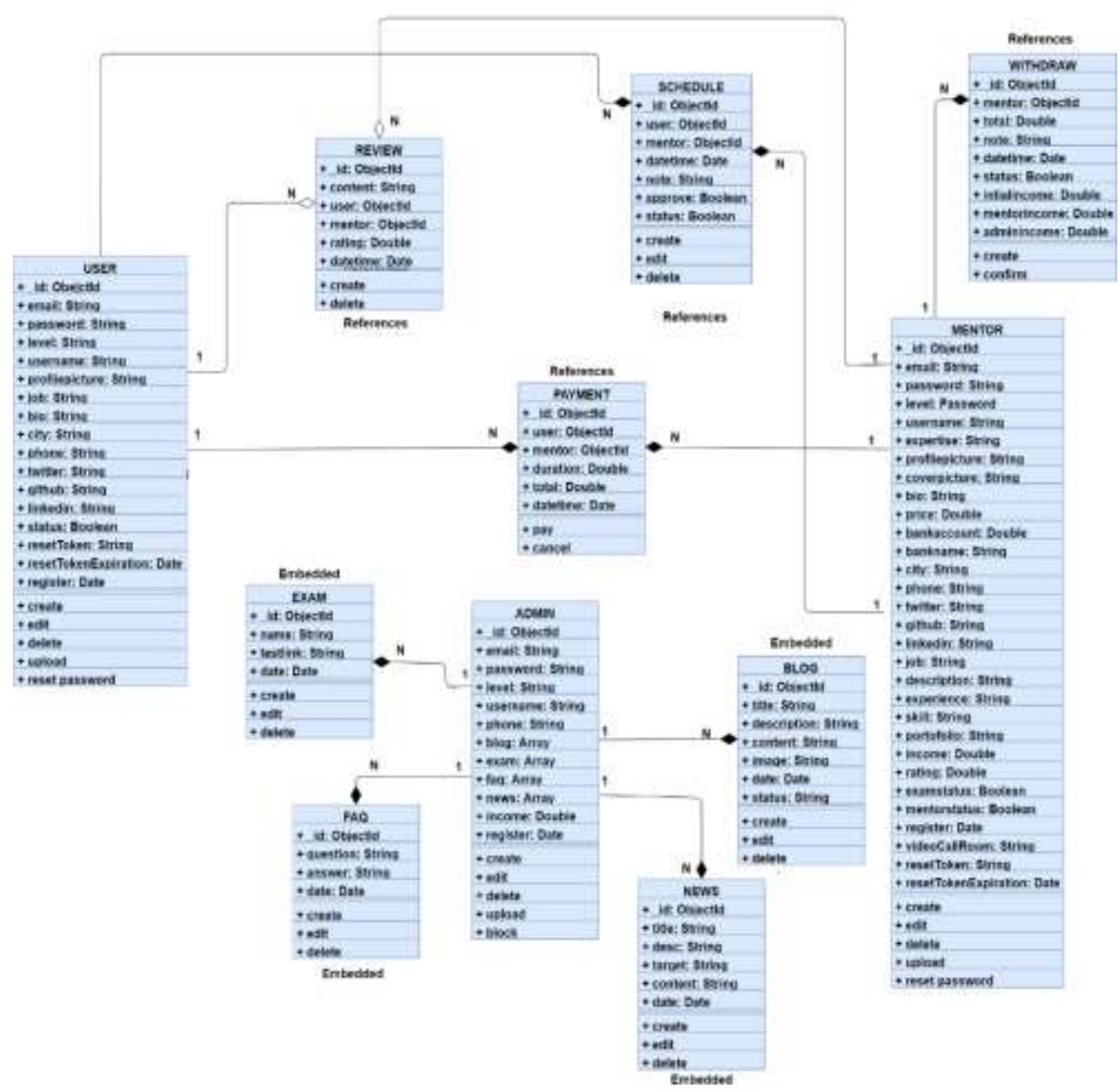

Gambar 3. Class Diagram 
4. Perancangan Antarmuka

Perancangan antar muka adalah merupakan tahapan desain sistem yang mempertimbangkan kemudahan user dalam menggunakan aplikasi sistem bisa user friendly, sehingga pelibatan user dalam proses design harus dilakukan, dan berikut adalah hasil desain interface untuk Sistem Informasi Tracer Study di Universitas Banten Jaya.

a. Struktur menu

Stuktur menu digunakan dalam Digunakan memetakan aktifitas-aktifitas yang ada dalam sistem informasi, sehingga memudahkan user dalam berintekasi dengan sistem informasi yang. Berikut adalah tampilan struktur menu pada penitilian ini :

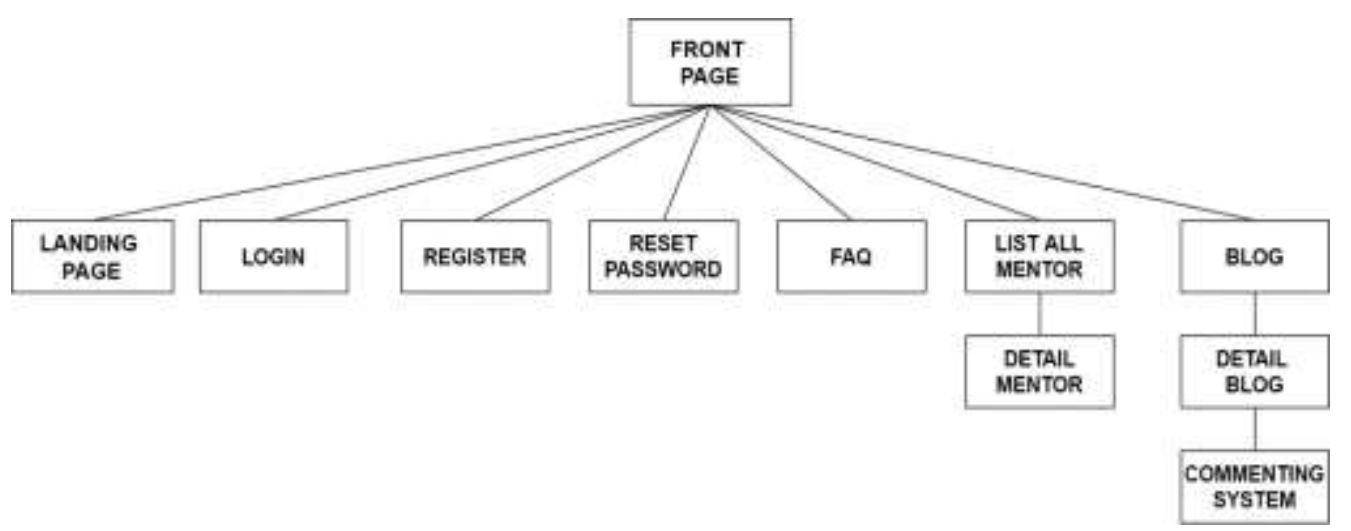

Gambar 4. struktur fitur frontpage

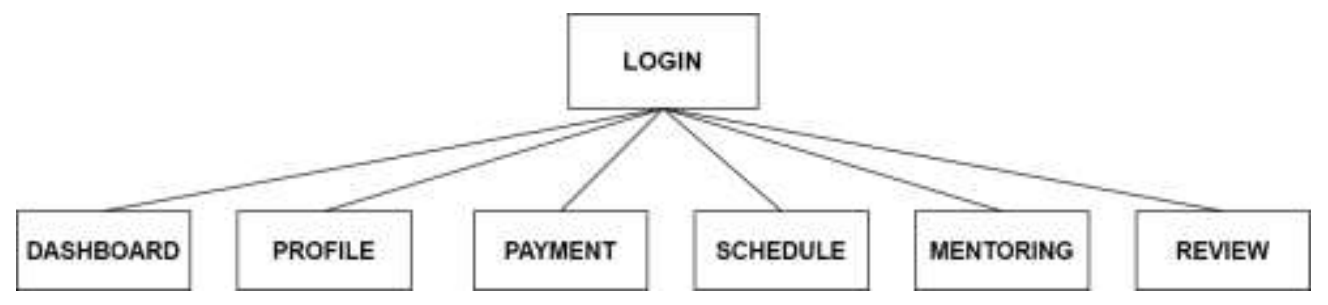

Gambar 5. struktur fitur user 


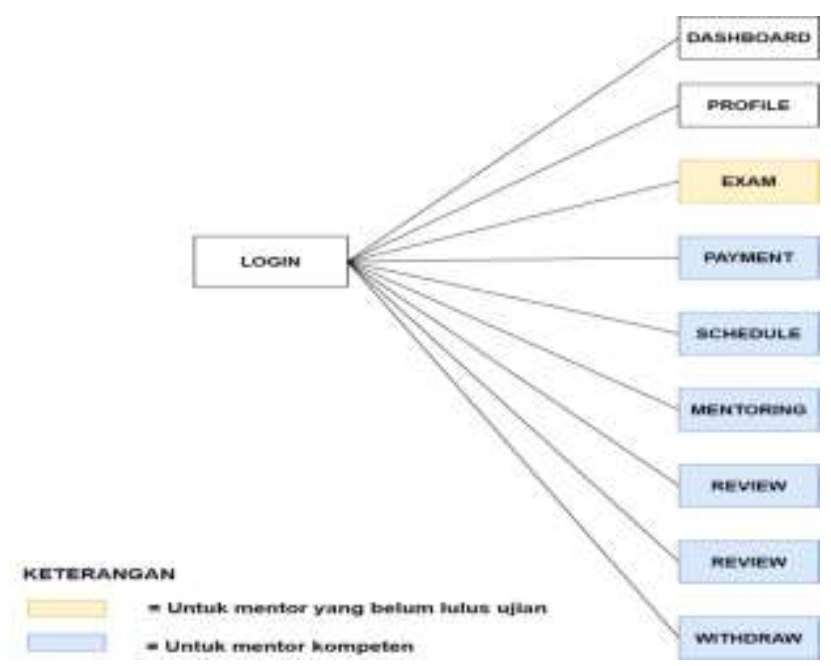

Gambar 6. struktur fitur mentor

b. Struktur Tampilan Input / Form Input

Untuk Hak akses atau fitur yang tersedia bagi admin cukup banyak diantara detailnya adalah sebagai berikut:

a) Dashboard: Berisi statistik informasi terkini dari sistem secara keseluruhan

b) Mentor: Berisi semua informasi mengenai mentor

c) User: Berisi semua informasi mengenai user

d) Payment: Berisi semua informasi mengenai pembayaran

e) Withdraw: berisi semua informasi mengenai permintaan pencairan dana

f) Mentoring: Berisi semua informasi tentang video call room yang digunakan untuk proses mentoring

g) Profile: Berisi semua informasi tentang profile admin dan perubahan password

h) Blog: Berisi informasi mengenai blog atau artikel

i) Exam: Berisi semua informasi mengenai link soal ujian untuk mentor

j) FAQ: Berisi semua informasi pertanyaan dan jawaban yang sering ditanyakan

k) News: Berisi semua informasi terkini yang ditujukan kepada user atau mentor terkait 
1) Message: Berisi semua informasi pesan masuk dan keluar. Berikut tampilan aplikasi messaging yang digunakan admin versi web dan mobilenya.

m)Payment Gateway : Berisi semua informasi transaksi lengkap beserta report yang terintegrasi dengan aplikasi Expert Assist.

n) Container Portainer : Aplikasi ini bisa diakses hanya oleh admin dan terintegrasi dengan aplikasi Expert Assist.

o) Container Boatswain : Aplikasi ini bisa diakses hanya oleh admin dan terintegrasi dengan aplikasi Expert Assist.

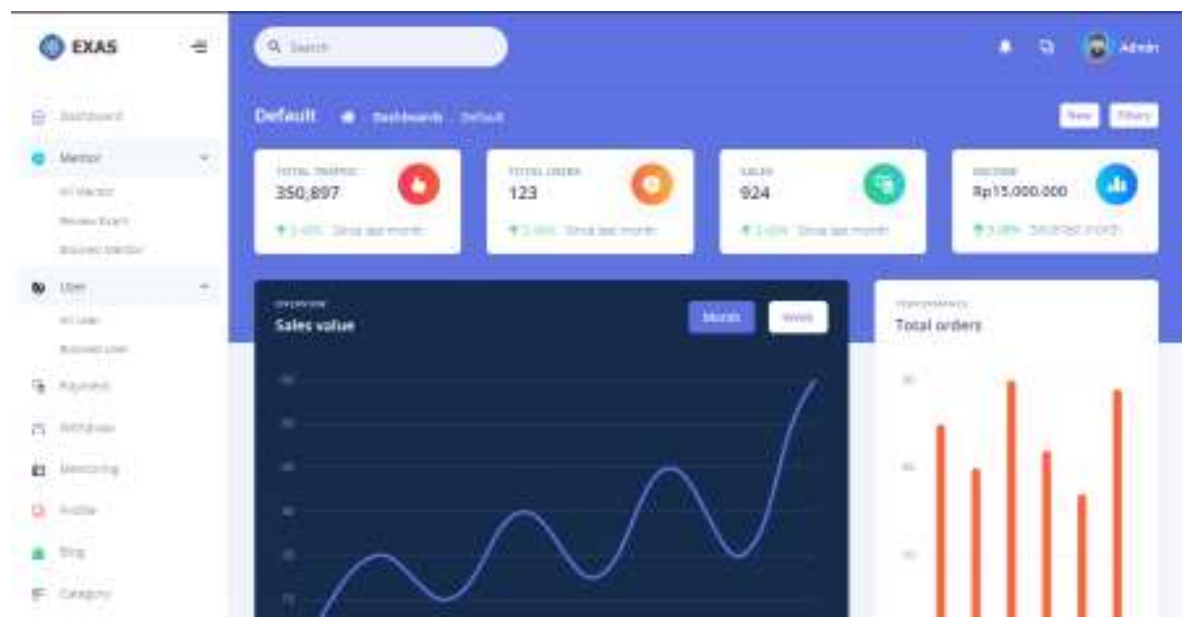

Gambar 7. Dashboard Admin pada aplikasi Expert Assist
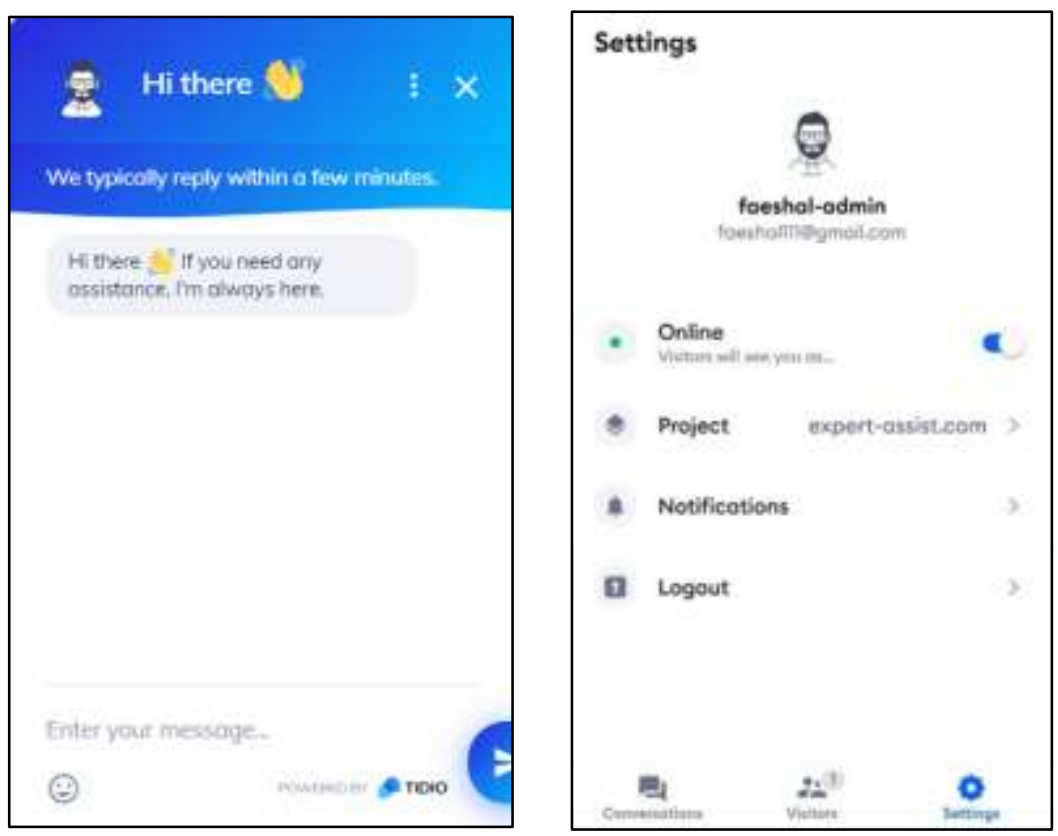

Gambar 8. UI fitur Messaging versi Web dan Mobile App 


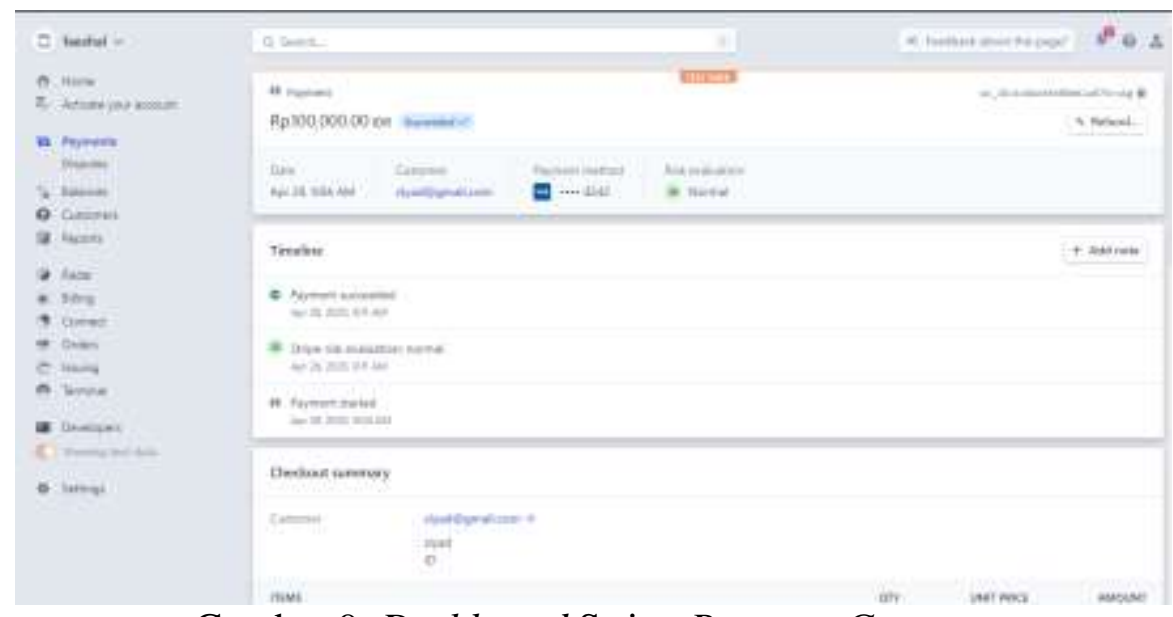

Gambar 9. Dashboard Stripe Payment Gateway

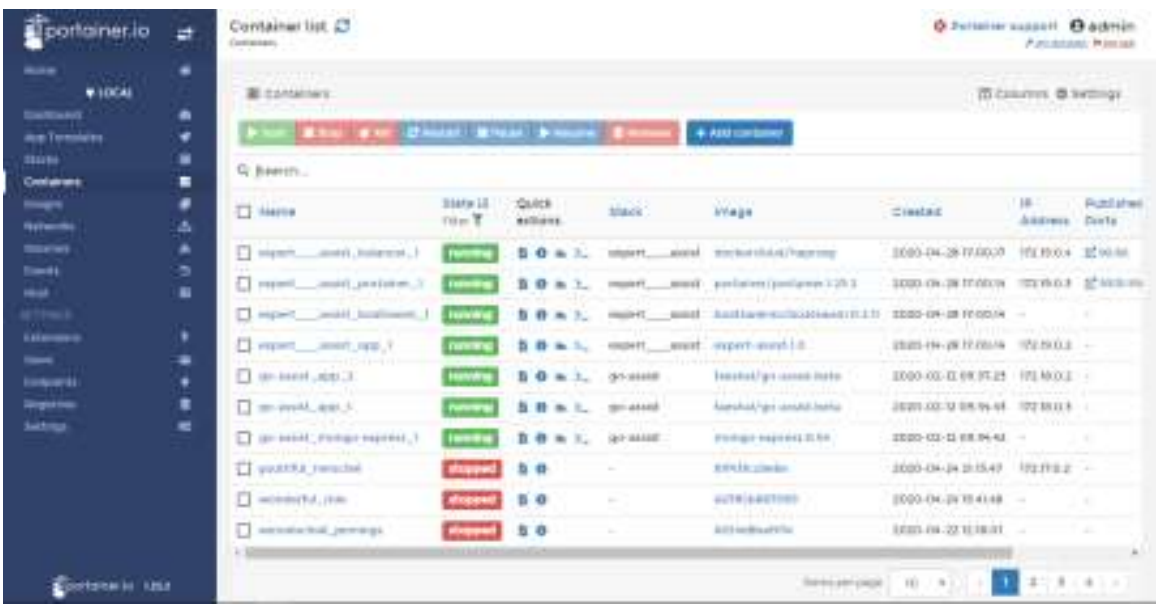

Gambar 10. Dashboard Container Portainer

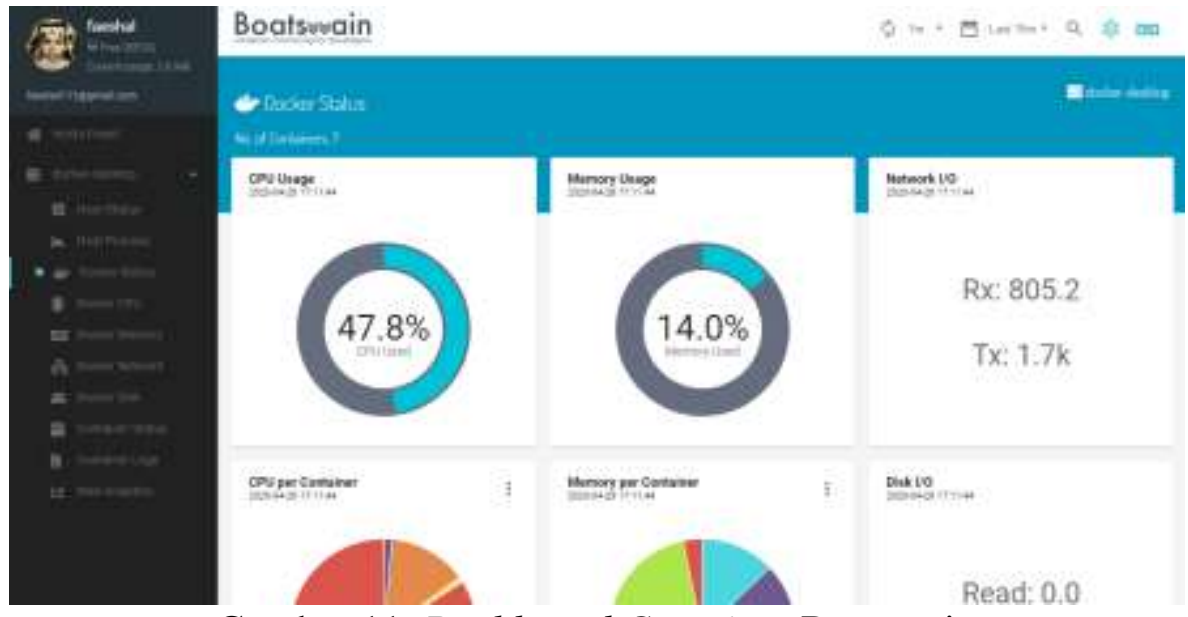

Gambar 11. Dashboard Container Boatswain 
c. Uji coba dan Hasil

Black box testing adalah metode pengujian perangkat lunak yang digunakan untuk menguji perangkat lunak dengan menguji fungsionalitasnya tanpa menganlisa struktur internal kode program. Berikut adalah hasil dari pengujian pada aplikasi Expert Assist:

Tabel 2. Tabel Skenario Black Box Testing

\begin{tabular}{|c|c|c|}
\hline FITUR & SKENARIO & HASIL \\
\hline \multicolumn{3}{|c|}{ Halaman Frontend } \\
\hline Register & $\begin{array}{l}\text { Mendaftarkan akun ke semua level } \\
\text { berikut uji coba validasi dan sanitasi data }\end{array}$ & Sesuai \\
\hline Login & $\begin{array}{l}\text { Login akun di setiap level berikut uji } \\
\text { coba validasi dan sanitasi data }\end{array}$ & Sesuai \\
\hline $\begin{array}{l}\text { Reset } \\
\text { Password }\end{array}$ & $\begin{array}{l}\text { Reset Password berikut dengan uji } \\
\text { validasi dan sanitasi data }\end{array}$ & Sesuai \\
\hline FAQ & Akses FAQ page & Sesuai \\
\hline $\begin{array}{l}\text { Mentor List \& } \\
\text { Detail }\end{array}$ & $\begin{array}{l}\text { Akses Mentor List \& Detail setiap } \\
\text { mentor }\end{array}$ & Sesuai \\
\hline $\begin{array}{l}\text { Blog \& } \\
\text { Comment }\end{array}$ & $\begin{array}{l}\text { Akses blog page, detail setiap blog dan } \\
\text { melakukan komentar di setiap blog post }\end{array}$ & Sesuai \\
\hline \multicolumn{3}{|l|}{ Halaman User } \\
\hline Dashboard & $\begin{array}{l}\text { Akses dashboard dan memverifikasi } \\
\text { validitas data }\end{array}$ & Sesuai \\
\hline Profile & $\begin{array}{l}\text { Malakukan update profile \& perubahan } \\
\text { password }\end{array}$ & Sesuai \\
\hline Payment & Melakukan transaksi pembayaran & Sesuai \\
\hline Schedule & $\begin{array}{l}\text { Melakukan permintaan jadwal mentoring } \\
\text { dan pembatalan jadwal }\end{array}$ & Sesuai \\
\hline Mentoring & Melakukan video call dengan mentor & Sesuai \\
\hline Review & Melakukan transaksi pembayaran & Sesuai \\
\hline \multicolumn{3}{|c|}{ Halaman Mentor } \\
\hline Dashboard & $\begin{array}{l}\text { Akses dashboard dan memverifikasi } \\
\text { validitas data }\end{array}$ & Sesuai \\
\hline Profile & $\begin{array}{l}\text { Malakukan update Profile \& perubahan } \\
\text { password }\end{array}$ & Sesuai \\
\hline Exam & $\begin{array}{l}\text { Melakukan ujian berdasarkan bidang } \\
\text { keahlian yang dipilih }\end{array}$ & Sesuai \\
\hline Payment & $\begin{array}{l}\text { Akses transaksi pembayaran yang sudah } \\
\text { dilakukan berdasarkan mentorId }\end{array}$ & Sesuai \\
\hline Schedule & Melakukan persetujuan jadwal mentoring & Sesuai \\
\hline Mentoring & Melakukan video call dengan user & Sesuai \\
\hline Review & Akses review page berdasarkan mentorId & Sesuai \\
\hline Withdraw & Melakukan permintaan Tarik dana & Sesuai \\
\hline
\end{tabular}




\begin{tabular}{|c|c|c|}
\hline Dashboard & $\begin{array}{l}\text { Akses dashboard dan memverifikasi } \\
\text { validitas data }\end{array}$ & Sesuai \\
\hline Profile & $\begin{array}{l}\text { Malakukan update profile \& perubahan } \\
\text { password }\end{array}$ & Sesuai \\
\hline Exam & $\begin{array}{l}\text { Melakukan penilaian ujian mentor dan } \\
\text { akses data seluruh calon mentor }\end{array}$ & Sesuai \\
\hline Mentor & $\begin{array}{l}\text { Melakukan akses data seluruh mentor } \\
\text { yang sudah kompeten dan melakukan } \\
\text { pemblokiran }\end{array}$ & Sesuai \\
\hline User & $\begin{array}{l}\text { Melakukan akses data seluruh } \text { user yang } \\
\text { dan melakukan pemblokiran }\end{array}$ & Sesuai \\
\hline Payment & Akses semua pembayaran yang masuk & Sesuai \\
\hline Schedule & Akses semua jadwal mentoring & Sesuai \\
\hline Mentoring & $\begin{array}{l}\text { Akses semua video call room yang telah } \\
\text { dibuat \& memanipulasi datanya }\end{array}$ & Sesuai \\
\hline Review & $\begin{array}{l}\text { Akses semua review yang telah dibuat } \\
\text { user }\end{array}$ & Sesuai \\
\hline Withdraw & $\begin{array}{l}\text { Menerima permintaan tarik dana dari } \\
\text { mentor dan menolaknya }\end{array}$ & Sesuai \\
\hline Blog & $\begin{array}{l}\text { Melakukan operasi CRUD pada blog } \\
\text { page }\end{array}$ & Sesuai \\
\hline News & Melakukan operasi CRUD pada News & Sesuai \\
\hline Message & $\begin{array}{l}\text { Akses pesan \& membalas pesan yang } \\
\text { masuk via mobile app \& website }\end{array}$ & Sesuai \\
\hline Comment & Akses Comment yang masuk & Sesuai \\
\hline FAQ & $\begin{array}{l}\text { Melakukan operasi CRUD pada FAQ } \\
\text { page }\end{array}$ & Sesuai \\
\hline
\end{tabular}

\section{KESIMPULAN}

Berdasarkan pembahasan pada bab-bab sebelumnya, maka dapat ditarik beberapa kesimpulan yaitu :

1. Teknologi Asynchronous atau Non Blocking pada Node.JS terbukti lebih cepat dan memiliki performa yang jauh lebih baik dibandingkan bahasa pemrograman server side konvernsional yang menganut mekanisme Blocking Code.

2. Arsitektur sistem yang dibangun diatas Container Docker terbukti dapat membantu proses pengembangan aplikasi menjadi lebih cepat, membuat aplikasi lebih Portable, Secure, Scalable, Robust dengan tetap menghemat sumber daya, membantu menyamakan konfigurasi environment development dan production serta menghindari konflik antar aplikasi yang berjalan 
dimesin yang sama sehingga akan meninggkakan produktifitas developer dan performa sistem yang dibangun.

3. Aplikasi Expert Assist berhasil menjawab permasalahan pada masyarakat yaitu belum adanya aplikasi yang mempertemukan mentor/expert dengan user. Aplikasi telah diuji dan semuanya berjalan sesuai harapan.

\section{DAFTAR PUSTAKA}

Alauddin, M. F., Ijtihadie, R. M., \& Husni, M. (2017). Implementasi Virtual Data Center Menggungakan Linux Container Berbasis Docker dan SDN. Jurnal Teknik ITS, 6(2), 6-8. https://doi.org/10.12962/j23373539.v6i2.23755

Analysis of its Performance. IJCSNS International Journal of Computer Science and Network Security, 17(3), 228-235.

Bashari Rad, B., John Bhatti, H., \& Ahmadi, M. (2017). An Introduction to Docker and

Bhatia, G. (2017). Available Online at www.ijarcs.info THE ROAD TO DOCKER : A SURVEY (Vol. 8, Issue 0976, pp. 83-88).

Christensson, P. (2017, August 21). Container Definition. Retrieved 2020, Sep 3, from https://techterms.com

Docker.com. (2019). What is a container ? A Standarized unit of software, https://www.Docker.com/resources/what-container

G, S. (2019). A Novel Approach for Remote Compilation using Docker Containers. International Journal of Computer Communication and Informatics. https://doi.org/10.34256/ijcci1918

Hamori, Farenc, Gergely Nemeth, (2019), History of NodeJS on a Timeline, https://blog.risingstack.com/history-of-node-js/

Hibbard, James, Camilo Reyes, (2018), NodeJS The Collection, Melbourne In Sitepoint

ID-Networkers, (2017), Operation \& Administration Docker, Jakarta In IDN

Jain, V., \& Upadhyay, A. (2017). MongoDB and NoSQL Databases. International Journal of Computer Applications, 167(10), 16-20. https://doi.org/10.5120/ijca2017914385

Kleppmann, M. (2017). Designing Data-Intensive Applications: The Big Ideas behind Reliable, Scalable, and Maintainable Systems. In O'Reilly Media, Inc. 
Martin, R. C. (2017). Clean Architecture: A Craftsman's Guide to Software Structure and Design. In Prentice Hall. https://doi.org/10.1177/1356389011400889

Matthias, Karl, Sean P.Kane, (2015), Docker Up \& Running,California In O'ReillyMead Andrew, (2018), Learning Node.JS Development, Birmingham In Packt

MongoDB.com, (2019). MongoDB Introduction \& Documentation https://docs.mongodb.com/

Mouat, A. (2015). Using Docker. In $O^{\prime}$ Reilly. www.allitebooks.com

Murugan, P., Subramanian, S., \& Rajinigirinath, V. P. | D. D. (2018). Using Docker for Containerization in High Performance Computing Applications. International Journal of Trend in Scientific Research and Development, Volume-2(Issue-3), 2005-2009. https://doi.org/10.31142/ijtsrd11591

Raharjo, Budi, (2019), Pemrograman Web Dengan Node.JS dan JavaScript, Bandung In Informatika

ROMADLON BIK, M. (2017). Implementasi Docker Untuk Pengelolaan Banyak Aplikasi Web (Studi Kasus : Jurusan Teknik Informatika Unesa). Jurnal Manajemen Informatika, 7(2), 46-50.

Rompis, A. C., \& Aji, R. F. (2018). Perbandingan Performa Kinerja Node.js, PHP, dan Python dalam Aplikasi REST. CogITo Smart Journal, 4(1), 171. https://doi.org/10.31154/cogito.v4i1.92.171-187

Tankersley, Chris, (2016), Docker For Developers, British Columbia In Leanpub Sharma, A., Kumar, R., \& Mansotra, V. (2016). Proposed Stemming Algorithm for Hindi Information Retrieval. International Journal of Innovative Research in Computer an Communication Engineering (An ISO Certified Organization), 3297(6), 11449-11455. https://doi.org/10.15680/IJIRCCE.2016

Williams, Alex, (2019), The Docker Container \& Ecosystem, New York In The New Stack 